\title{
VDR gene polymorphism and trace elements in Thai postmenopausal women with risk of osteoporosis: Cross -sectional study
}

\author{
Yuttana Sudjaroen ${ }^{*}$, Kanittada Thongkao, Pimporn Thongmuang ${ }^{2}$, Wanida Pongstaporn ${ }^{3}$, Doungchan Aounchat ${ }^{4}$, Kowit \\ Suwannahong ${ }^{4}$ \\ ${ }^{1}$ Department of Applied Science, Faculty of Science and Technology, Suan Sunandha Rajabhat University, Bangkok, Thailand. \\ ${ }^{2}$ Department of Aesthetic Health Science, College of Allied Health Science, Suan Sunandha Rajabhat University, Samut Songkhram, Thailand. \\ ${ }^{3}$ Department of Medical Science, Faculty of Science, Rangsit University, Pathumthani, Thailand. \\ ${ }^{4}$ Department of Environmental Health, Faculty of Public Health, Burapha University, Chonburi, Thailand.
}

\begin{tabular}{l}
\hline ARTICLE INFO \\
\hline Received on: 01/07/2021 \\
Accepted on: 17/11/2021 \\
Available Online: 05/02/2022
\end{tabular}

Key words:

Bone marker, BMD, FokI polymorphism, osteoporosis, trace elements, VDR.

\begin{abstract}
Osteoporosis is the loss of bone density and it increases the risk of fracture. The FokI polymorphism (C>T; rs2228570) of the vitamin D receptor (VDR) has a significant correlation with bone mineral density (BMD) reduction. Deficiencies of trace elements increase the risk of osteoporosis during menopause. This study aimed to compare and correlate bone-related parameters and trace elements and to identify FokI genotypes and estimate its osteoporosis risk between normal and risk groups of postmenopausal women. Seventy subjects were randomly recruited in this study. BMD was determined by a quantitative ultrasound bone densitometer. The normal group $(N=24)$ included women with normal BMD status, while the low-BMD group $(N=46)$ included women with osteoporosis and osteopenia. Serum alkaline phosphatase (ALP), calcium (Ca), and magnesium (Mg) were measured by an automatic analyzer. Serum zinc ( $\mathrm{Zn}$ ) and selenium (Se) were extracted and analyzed by inductively coupled plasma-optical emission spectrometry. The FokI genotypes of the VDR gene were amplified and identified by the polymerase chain reaction-restriction fragment length polymorphism. BMD was significantly negatively correlated with ALP and $\mathrm{Ca}(r=-0.239$ and -0.673$)$ and positively correlated with $\mathrm{Mg}$ and $\mathrm{Zn}(r=0.327$ and 0.383$)$. The homozygous recessive (TT) genotype of the FokI polymorphism was susceptible to osteoporosis (odds ratio $=2.69$ ). We concluded that FokI Single nucleotide polymorphisms and bone markers may be useful in osteoporosis management in Thai postmenopausal women.
\end{abstract}

\section{INTRODUCTION}

Osteoporosis progresses without any symptoms until a bone fracture occurs. Osteoporotic fractures are a common problem in public health control and intervention, which relate to increasing immobility and mortality, affecting quality of life, and high economic impact due to extended hospital stay (Black and Rosen, 2016; Kawalkar, 2015). Intervention policies are necessary to diagnose and reduce the risk of fractures (Si et al., 2015; Williams et al., 2021). There are various associated factors, such as female gender (Black and Rosen, 2016; Pietschmann et al.,

\footnotetext{
*Corresponding Author

Yuttana Sudjaroen, Department of Applied Science, Faculty of Science and Technology, Suan Sunandha Rajabhat University, Bangkok, Thailand. E-mail: yuttana.su@ssru.ac.th
}

2009), old age (Aspray and Hill, 2019; Giusti and Bianchi, 2014), calcium intake (Cano et al., 2018), vitamin D level (Cano et al., 2018; Weaver et al., 2016), and genetic variations (Conti et al., 2015; He et al., 2015; Kubota et al., 2001). There are various genes involved in osteoclast proliferation, which are associated with bone mass reduction or osteoporotic fractures, including the vitamin D receptor (VDR), estrogen receptor, and collagen type I alpha-I genes (Stewart and Ralston, 2000).

Vitamin D and its active metabolites participate in the processes of bone tissue mineralization, maintaining calcium homeostasis, and bone remodeling, which are mediated through the VDR (Ahn et al., 2009). The variations VDR gene polymorphisms have been reported, and VDR genotypes are associated with bone diseases, including multiple sclerosis, osteoporosis, vitamin D-dependent rickets type II (Cantorna and Mahon, 2004; Jiang et al., 2020; Valdivielso and Fernandez, 2006), and essential hypertension (Banjabi et al., 2020). VDR 
gene polymorphisms occur in coding or noncoding regions, which can be changed in an amino acid sequence and also affect VDR expression (Uitterlinden et al., 2004). Single nucleotide polymorphisms (SNPs) of the VDR gene can be identified with the proper restriction endonucleases such as FokI, ApaI, TaqI, and $B s m I$ by the polymerase chain reaction-restriction fragment length polymorphism (PCR-RFLP) technique. Recently, VDR gene variants and the risk of osteoporosis have been associated with ethnic differences (Abbasi et al., 2012; Eisman, 1995; Jiang et al., 2020; Zintzaras et al., 2006). The FokI polymorphism (C>T; rs2228570) of the VDR gene was significantly correlated with bone mineral density (BMD) reduction at the lumbar spine and elevation of hip bone loss in osteoporotic Mexican-American women (Gross et al., 1996). The association of the haplotype of TaqI, FokI, and BsmI SNPs of the VDR gene had been reported where the $\mathrm{T}$ allele was a risk factor for osteoporosis in an Indian population (Singh et al., 2013). FokI SNPs could be a link between calcium and vitamin D intake, BMD level, and osteoporosis in obese Iranian women (Moradi et al., 2017). FokI SNPs were also a significant risk factor for osteoporosis in Thai postmenopausal women with osteoporosis, and the TT genotype was susceptible to osteoporosis [odds ratio $(\mathrm{OR})=2.30$ ] (Techapatiphandee et al., 2018).

Nutritional disturbances, especially deficiencies of trace elements and vitamins, pose increased risk for osteoporosis during menopause. Elements maintain skeleton development and function in the bone matrix (Howard et al., 1992). Abnormal metabolism of trace elements may play a role in osteoporosis development (Liu et al., 2009; Nieves, 2005; Odabasi et al., 2008). In addition, trace element supplementation with or without calcium $(\mathrm{Ca})$ can increase BMD in postmenopausal women (Saltman and Strause, 1991). Early BMD screening for osteoporosis in Thai postmenopausal women is needed to focus on the community level (Sudjaroen and Thongmuang, 2019; Sudjaroen and Thongmuang, 2020), and calcium and vitamin D supplementation in a pilot study improved bone biochemical parameters (Sudjaroen and Thongmuang, 2018). This study aimed to compare and correlate bone-related parameters (i.e., BMD, $\mathrm{Ca}$ and alkaline phosphatase, and ALP) and trace elements [magnesium (Mg), zinc ( $\mathrm{Zn})$, and selenium (Se)] and to identify the genotypes of FokI SNPs and estimate its osteoporosis risk between normal and risk groups of postmenopausal women.

\section{MATERIALS AND METHODS}

\section{Subject recruitment}

This research was a cross-sectional study during the period from December 2020 to March 2021. Approximately 1,500 participants were in the Public Health Service Program in the Osteoporosis Prevention Program, which was under the responsibility of the Samut Songkhram Provincial Government Office and Samut Songkhram Education Centre, Suan Sunandha Rajabhat University. Seventy subjects were randomly recruited in this study. Inclusion criteria were as follows: postmenopausal women who 1) were aged $\geq 55-65$ years, 2) were conscious and interactive, and 3) had no serious symptom conditions. Exclusion criteria were as follows: women who had 1) complications with metabolic bone diseases, 2) a previous accident with a fracture, and 3) a pathological fracture (Gao et al., 2015). Anthropometric data were recorded by interviews during health service provision. The Ethics Committee of Suan Sunandha Rajabhat University approved this research protocol (COA.1-050-2020). The Director of the Osteoporosis Prevention Program permitted work on this research. All subjects were informed and consented.

\section{BMD measurements}

BMD was determined by a calcaneal quantitative ultrasound bone densitometer (SONOST-2000, OsteoSys, Korea), and the instrument operation and data interpretations were made according to manufacturer instruction. Interpretation was made according to BMD status, which was categorized as osteoporotic ( $\mathrm{T}$ score at or below -2.5 ), osteopenic ( $\mathrm{T}$ score between -1.0 and -2.5 ), and normal ( $\mathrm{T}$ score at above -1.0$)$ postmenopausal women. The normal postmenopausal women group $(N=24)$ had a normal BMD status, and the low-BMD postmenopausal women group $(N=46)$ included the osteoporotic and osteopenic status.

\section{Blood collection and biochemical measurement}

Each $5 \mathrm{ml}$ blood sample was obtained by venipuncture from the median cubital vein during the morning (7-9 a.m.) and drawn into clotting blood and Ethylenediaminetetraacetic acid (EDTA) tubes for 3 and $2 \mathrm{ml}$, respectively. The clotting blood tube was further centrifuged, and serum was separated within 2 hours (Young and Bermes, 1999). Serum ALP, Ca, and Mg were measured by an automatic analyzer, COBAS c501 (Roche-Diagnostics, Rotkreuz, Switzerland). Zn and Se from the serum in the clotting blood tube were extracted and analyzed (Roychowdhury et al., 2002; Wach et al., 2018) by inductively coupled plasma-optical emission spectrometry (Avio200, Perkin Elmer, Thailand).

\section{DNA extraction and genotype analysis}

Whole blood contained in EDTA tubes was prepared for genomic DNA extraction by using the QIAamp Blood DNA Mini Kit (QIAGEN Thailand, Bangkok, Thailand), and genomic DNA was stored at $-20^{\circ} \mathrm{C}$. Genomic DNA was amplified along with the genotype of the FokI (rs2228570) SNPs of the VDR gene by PCR-RFLP. The primers were reverse primer (3 $\phi^{\prime}$-TTGTACCCTGCCCGCAAGAAA-5' $\phi$ ) and forward primer $\left(5^{\prime} \phi\right.$-ACCAAGGATGCCAGCTGG-3' $\left.\phi\right)$. The PCR mixture used was OnePCR Ultra Supermix with a fluorescent dye (Bio-Helix, Gibthai, Thailand). The reaction conditions were optimized for initial denaturation at $94^{\circ} \mathrm{C}$ for 5 minutes followed by 40 cycles of denaturation at $94^{\circ} \mathrm{C}$ for 30 seconds, annealing at $58^{\circ} \mathrm{C}$ for 30 seconds and extension at $72^{\circ} \mathrm{C}$ for 60 seconds, and one step of final extension at $72^{\circ} \mathrm{C}$ for 10 minutes in a thermal cycler (Prasad et al., 2021; Techapatiphandee et al., 2018). The amplified PCR product was $266 \mathrm{bp}$, which was confirmed by agarose gel electrophoresis. The PCR amplified product $(20 \mathrm{ml})$ was conducted with RFLP by using $0.4 \mathrm{ml}$ of the FokI restriction endonuclease enzyme (R0109S, NEB), $2.5 \mathrm{ml}$ of reaction buffer, and $2.1 \mathrm{ml}$ of autoclaved water (total volume of reaction mixture $=25 \mathrm{ml}$ ). The reaction mixture was incubated at $37^{\circ} \mathrm{C}$ for 60 minutes in a water bath for making DNA fragments (Prasad et al., 2021) and genotyped in each sample by DNA fragment separation on $2.5 \%$ agarose gel electrophoresis along with DNA ladder (VC 100 bp DNA Ladder, Vivantis Technologies, Malaysia). DNA electropherogram was 
performed by Bio-Rad Universal Hood II-GelDoc System (BioRad Laboratories-Segrate, Italy). FokI SNPs were 266 bp (uncut) for the homozygous dominant (CC) genotype; 184 and $63 \mathrm{bp}$ (cut) for the TT genotype; and 266, 184, and $63 \mathrm{bp}$ (cut/uncut) for the heterozygous (CT) genotype (Techapatiphandee et al., 2018). Direct sequencing confirmed genotypes in $15 \%$ of randomized samples.

\section{Statistical analysis}

Descriptive data was represented by using mean, standard deviation, and frequency. The independent $t$-test was used for the comparison of individual and biochemical parameters between the normal and risk (low-BMD) groups. Pearson's correlation was used to analyze the relationship between individual and biochemical parameters. Chi-square was used to calculate odd risk estimation on different FokI genotypes. Statistical analysis was conducted by the SPSS 21.0 software.

\section{RESULTS AND DISCUSSION}

\section{Bone-related parameters and trace elements in postmenopausal women}

Age between the normal and low-BMD (risk) groups was not significantly different. ALP and serum Ca of the risk group were significantly higher than in the normal group ( $p=0.035$ and $<0.0001$ ); therefore, they were within reference ranges. Serum $\mathrm{Mg}, \mathrm{Zn}$, and $\mathrm{Se}$ of the risk group were significantly lower than in the normal group ( $p=0.012,0.04$, and 0.028 , respectively). Serum $\mathrm{Zn}$ in the risk group and $\mathrm{Se}$ in both groups were lower than reference ranges (Table 1 ). BMD was significantly negatively correlated with ALP and $\mathrm{Ca}(r=-0.239$ and -0.673$)$ and positively correlated with $\mathrm{Mg}$ and $\mathrm{Zn}(r=0.327$ and 0.383$)$. Serum calcium was significantly negatively correlated with all trace elements. The correlation of serum $\mathrm{Zn}$ and Se was the strongest $(r=0.824)$ due to cofactors of antioxidant enzymes (Table 2).
Previous studies reported higher Ca and ALP (within reference ranges) in women with osteoporosis (Ali, 2018; Sasmita et al., 2015). Serum Ca was controlled and maintained homeostasis between the serum and bone compartment. Increasing of serum $\mathrm{Ca}$ and $\mathrm{BMD}$ reduction in osteoporotic women were implied to have a negative correlation between serum $\mathrm{Ca}$ and BMD status (Ali, 2018; Rana, 2013). ALP is a clinical marker of bone metabolism, and its activity arises from the bone and liver. The ALP level of the risk and normal groups was significantly different; therefore, it was still within the reference range. A significant finding was represented in the relationship of the BMD status or osteoporosis and ALP (Narula et al., 2013). Mg is an important mineral for bone cell function especially osteoblast mitogenicity. Thus, when $\mathrm{Mg}$ has a deficit, the growth of osteoblasts will be inhibited (Rude and Gruber, 2004). A significant difference of Mg between the osteoporotic and healthy postmenopausal women was also observed in red blood cells, which was described by the $\mathrm{Mg}$ transport mechanism into the cell in osteoporosis (Odabasi et al., 2008). $\mathrm{Zn}$ is an essential element for over 200 enzymes, collagen production, and bone mineralization (Hyun et al., 2004). Se is also important for human health, and depletion of Se will affect bone tissue (Chariot and Bignani, 2003). Oxidative stress is implicated in postmenopausal osteoporosis by loss of balance between antioxidative and oxidative markers. Monitoring of oxidative stress-related markers is useful for the diagnosis and prognosis of osteoporosis (Zhao et al., 2021). Hence, reduction of serum $\mathrm{Mg}, \mathrm{Zn}$, and Se in osteoporosis may affect the antioxidant status, especially antioxidant enzymes. Our finding was summarized in that serum $\mathrm{Ca}$ and ALP in the risk group were higher than in normal postmenopausal women, and serum $\mathrm{Mg}, \mathrm{Zn}$, and $\mathrm{Se}$ will reduce along with BMD during osteoporosis progress. High serum $\mathrm{Ca}$ in postmenopausal women is a risk for bone loss, and estrogen deficit increases bone turnover and bone resorption. Hence, the hormonal and BMD status in females are important factors, which

Table 1. Comparison of normal and low BMD groups among postmenopausal women.

\begin{tabular}{|c|c|c|c|c|c|c|c|c|}
\hline Group & Frequency (\%) & $\begin{array}{c}\text { Age } \\
\text { (years) }\end{array}$ & $\begin{array}{c}\text { BMD } \\
\text { (T-score) }\end{array}$ & $\begin{array}{l}\text { ALP } \\
(\mathrm{U} / \mathbf{l}) \\
\end{array}$ & $\begin{array}{c}\mathrm{Ca} \\
(\mathrm{mg} / \mathrm{dl})\end{array}$ & $\begin{array}{c}\mathrm{Mg} \\
(\mathrm{mg} / \mathrm{dl}) \\
\end{array}$ & $\begin{array}{c}\mathrm{Zn} \\
(\mathrm{mg} / \mathrm{dl})\end{array}$ & $\begin{array}{c}\mathrm{Se} \\
(\mathrm{mg} / \mathrm{dl})\end{array}$ \\
\hline Normal BMD ${ }^{a}$ & $24(34.3)$ & $59.6 \pm 7.45$ & $0.69 \pm 0.87$ & $77.4 \pm 15.43$ & $9.1 \pm 0.40$ & $2.03 \pm 0.14$ & $61.4 \pm 19.9$ & $2.96 \pm 1.16$ \\
\hline Low BMD b & $46(65.7)$ & $61.2 \pm 10.5$ & $-1.98 \pm 0.86$ & $87.0 \pm 20.90$ & $9.9 \pm 0.71$ & $1.87 \pm 0.19$ & $46.4 \pm 17.9$ & $2.28 \pm 1.22$ \\
\hline$p$-value & - & 0.081 & - & $0.035^{*}$ & $<0.0001 * *$ & $0.012 *$ & $0.04 *$ & $0.028 *$ \\
\hline Reference range & - & - & $>-1.0$ & $30-120$ & $8.2-10.2$ & $1.8-2.5$ & $50-170$ & $8-25$ \\
\hline
\end{tabular}

Table 2. Pearson's correlation coefficient $(r)$ between BMD, age and biochemical parameters in postmenopausal women.

\begin{tabular}{ccccccc}
\hline & BMD & ALP & Ca & Mg & Zn & Se \\
\hline BMD & 1 & $-0.239 *$ & $-0.673 * *$ & $0.327 * *$ & $0.383 * *$ & 0.221 \\
$\mathrm{ALP}$ & $-0.239 *$ & 1 & 0.172 & -0.01 & -0.25 & 0.33 \\
$\mathrm{Ca}$ & $-0.673 * *$ & 0.172 & 1 & $-0.267 *$ & $-0.449 * *$ & $-0.374 * *$ \\
$\mathrm{Mg}$ & $0.327 * *$ & -0.01 & $-0.267 *$ & 1 & 0.172 & -0.041 \\
$\mathrm{Zn}$ & $0.383 * *$ & -0.25 & $-0.449 * *$ & 0.172 & 1 & $0.824 * *$ \\
$\mathrm{Se}$ & 0.221 & 0.33 & $-0.374 * *$ & -0.041 & $0.824 * *$ & 1 \\
\hline
\end{tabular}

*Statistically significant at $p<0.05$ level (two-tailed); ** Statistically significant at $p<0.01$. 


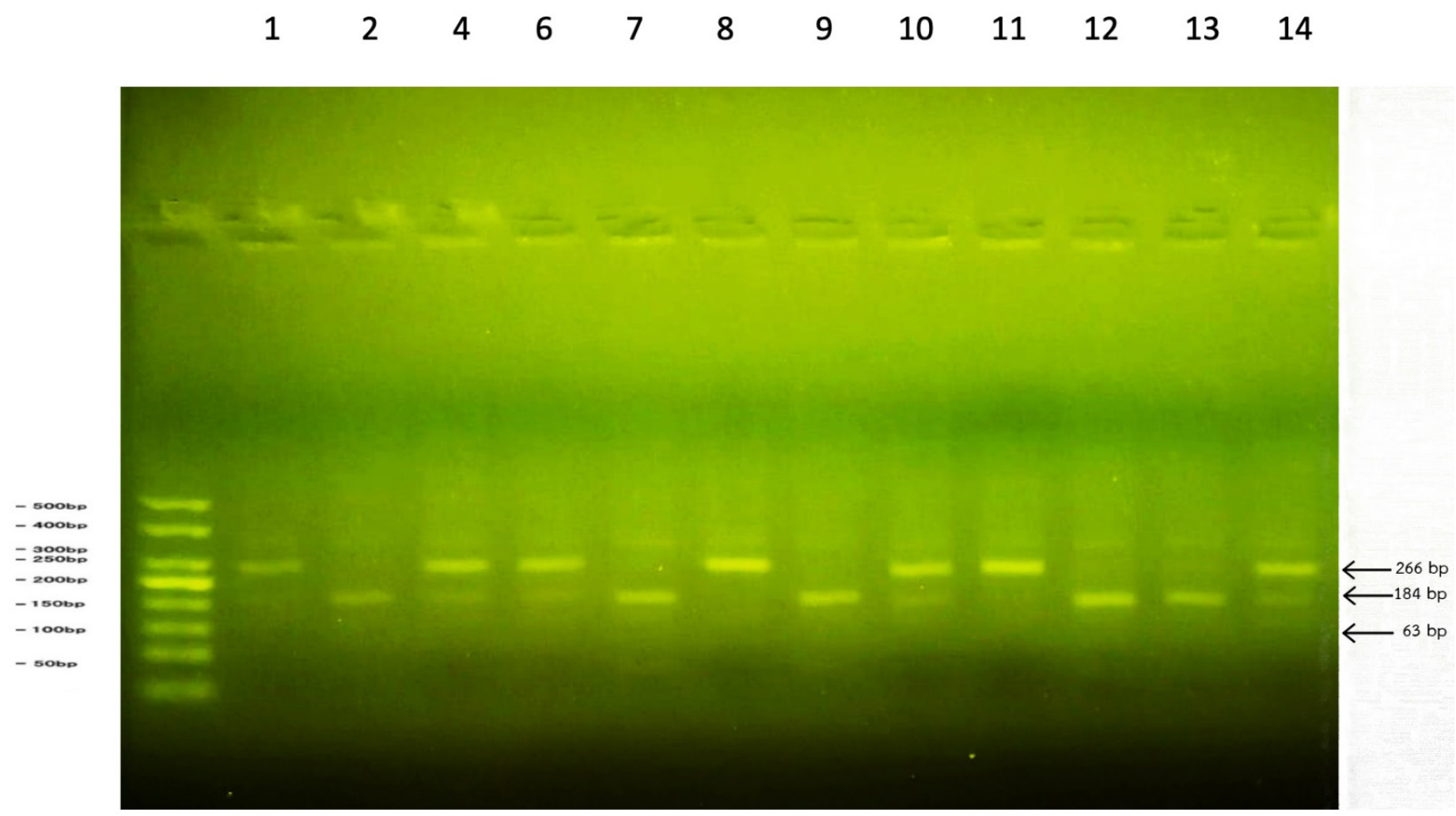

Figure 1. Identification of FokI polymorphism on VDR gene by PCR-RFLP: (a) CC genotype was represented as 266 bp fragment (uncut) in Lanes 8 and 11; (b) CT genotype was represented as 266, 184, and 63 bp fragments (heterozygous) in Lanes 4, 6, 10, and 14; and (c) TT genotype was represented as 184 and 63 bp fragments (homozygous recessive) in Lanes 2, 7, 9, 12, and 13.

Table 3. OR estimation in Fok I polymorphism of VDR gene (codominant model) between normal and risk (low BMD) groups.

\begin{tabular}{ccccc}
\hline Genotype & Normal group $(\boldsymbol{n}=\mathbf{2 4})$ & Risk group $(\boldsymbol{n}=\mathbf{4 6})$ & OR $(\mathbf{9 5} \% \mathbf{C I})$ & $\boldsymbol{p}$-value \\
\hline CC & $9(37.5 \%)$ & $6(13.0 \%)$ & $0.45(0.088-2.329)$ & $<0.001$ \\
CT & $13(54.2 \%)$ & $32(69.6 \%)$ & $1.00(0.359-2.789)$ & \\
TT & $2(8.3 \%)$ & $8(17.4 \%)$ & $2.69(0.508-4.882)$ & \\
\hline
\end{tabular}

should be addressed in osteoporosis studies (Dalemo et al., 2018; Lerner, 2006; Liu et al., 2019).

\section{FokI genotypes of VDR gene polymorphisms in postmenopausal women}

The DNA electrophoresis of the FokI genotypes identified a homozygous dominant (CC) for the $266 \mathrm{bp}$ fragment, heterozygous (CT) for the 266, 184, and 63 bp fragments, and homozygous recessive (TT) for the 184 and $63 \mathrm{bp}$ fragments (Fig. 1). The distribution of the $\mathrm{T}$ allele is more frequent in the risk group, and the TT genotype was high risk $(\mathrm{OR}=2.69$, 0.508-4.882) and susceptible to osteoporosis (Table 3). Our significant finding corresponded to a previous study, where it was reported that the FokI genotypes of the VDR gene were related to osteoporosis and the TT genotype was high risk and most susceptible in Thai osteoporotic patients (Techapatiphandee et al., 2018). We confirmed that these SNPs were useful in osteopenia and osteoporotic postmenopausal women with asymptomatic appearances and no history of fracture for at least the past 3 years. There was supportive evidence for osteoporosis occurrence in tropical countries, which have enough sunlight for vitamin D production. The FokI genotypes of the VDR gene were also related to primary hypertension (Prasad et al., 2021), periodontitis (Liu et al., 2020), and tumorigenesis (Rai et al., 2017). Identification of the FokI SNPs was used to predict osteoporotic progression in postmenopausal women without symptoms or fractures.

\section{CONCLUSION}

We concluded that serum $\mathrm{Ca}$ and ALP were negatively correlated with BMD. However, serum $\mathrm{Mg}, \mathrm{Zn}$, and Se were positively correlated with BMD in postmenopausal women. It was implied that osteoporosis was related to antioxidant reduction by trace element depletion. Identification of the FokI SNPs was used to predict osteoporotic progression in postmenopausal women without symptoms or fractures. 


\section{ACKNOWLEDGMENTS}

The authors are sincerely thankful to Suan Sunandha Rajabhat University, Bangkok, Thailand, for the supporting grant. They are grateful to Burapha University and Rangsit University, Thailand, for some laboratory support. They would also like to sincerely thank the students from the Applied Thai Traditional Medicine Program, College of Allied Health Sciences, Suan Sunandha Rajabhat University, for working with them as research assistants in the Osteoporosis Prevention Program.

\section{AUTHOR CONTRIBUTIONS}

All authors made substantial contributions to conception and design, acquisition of data, or analysis and interpretation of data; took part in drafting the article or revising it critically for important intellectual content; agreed to submit to the current journal; gave final approval of the version to be published; and agree to be accountable for all aspects of the work. All the authors are eligible to be an author as per the international committee of medical journal editors (ICMJE) requirements/guidelines.

\section{FUNDING}

There is no funding to report.

\section{CONFLICTS OF INTEREST}

The authors report no financial or any other conflicts of interest in this work.

\section{ETHICAL APPROVALS}

The Ethics Committee of Suan Sunandha Rajabhat University approved this research protocol (COA.1-0502020). The Director of the Osteoporosis Prevention Program permitted work on this research. All subjects were informed and consented.

\section{DATA AVAILABILITY}

The study data is available with authors.

\section{PUBLISHER'S NOTE}

This journal remains neutral with regard to jurisdictional claims in published institutional affiliation.

\section{REFERENCES}

Abbasi M, Hasani S, Sheikholeslami H, Alizadeh SA, Rashvand Z, Yazdi Z, Najafipour R. Association between vitamin D receptor Apa1 and Taq1 genes polymorphism and osteoporosis in postmenopausal women. $\mathrm{J}$ Qazvin Univ Med Sci, 2012; 16:4-10.

Ahn J, Albanes D, Berndt SI, Peters U, Chatterjee N, Freedman ND, Abnet CC, Huang WY, Kibel AS, Crawford ED, Weinstein SJ. Vitamin D-related genes, serum vitamin D concentrations and prostate cancer risk. Carcinogenesis, 2009; 30:769-76.

Ali NK. Estimation of some mineral (calcium, phosphorous, vitamin $25(\mathrm{OH}) \mathrm{D}$ and alkaline phosphatase) in osteoporosis patients in Kirkuk city. J Osteopor Phys Act, 2018; 6:215.

Aspray TJ, Hill TR. Osteoporosis and the ageing skeleton. Subcell Biochem, 2019; 91:453-76.

Banjabi AA, Al-Ghafari AB, Kumosani TA, Kannan K, Fallatah SM. Genetic influence of vitamin D receptor gene polymorphisms on osteoporosis risk. Int J Health Sci (Qassim), 2020; 14(4):22-8.
Black DM, Rosen CJ. Clinical practice postmenopausal osteoporosis. N Engl J Med, 2016; 374(3):254-62

Cano A, Chedraui P, Goulis DG, Lopes P, Mishra G, Mueck A, Senturk LM, Simoncini T, Stevenson JC, Stute P, Tuomikoski P. Calcium in the prevention of postmenopausal osteoporosis: EMAS clinical guide. Maturitas, 2018; 107:7-12.

Cantorna MT, Mahon BD. Mounting evidence for vitamin D as an environmental factor affecting autoimmune disease prevalence. Exp Biol Med (Maywood), 2004; 229:1136-42.

Chariot P, Bignani O. Skeletal muscle disorders associated with selenium deficiency in humans. Muscle Nerve, 2003; 27:662-8.

Conti V, Russomanno G, Corbi G, Toro G, Simeon V, Filippelli W, Ferrara N, Grimaldi M, D'Argenio V, Maffulli N, Filippelli A. A polymorphism at the translation start site of the vitamin $\mathrm{D}$ receptor gene is associated with the response to anti-osteoporotic therapy in postmenopausal women from southern Italy. Int J Mol Sci, 2015; 16:5452-66.

Dalemo S, Eggertsen R, Hjerpe P, Almqvist EG, Bostrom KB Bone mineral density in primary care patients related to serum calcium concentrations: a longitudinal cohort study from Sweden. Scand J Prim Health Care, 2018; 36:198-206.

Eisman JA. Vitamin D receptor gene alleles and osteoporosis: an affirmative view. J Bone Miner Res, 1995; 10:1289-93.

Gao LH, Zhu WJ, Liu YJ, Gu JM, Zhang ZL, Wang O, Xing $\mathrm{XP}, \mathrm{Xu}$ L. Physical performance and life quality in postmenopausal women supplemented with vitamin D: a two-year prospective study. Acta Pharmacol Sin, 2015; 36:1065-73.

Giusti A, Bianchi G. Treatment of primary osteoporosis in men Clin Interv Aging, 2014; 10:105-15.

Gross C, Eccleshall TR, Malloy PJ, Villa ML, Marcus R, Feldman D. The presence of a polymorphism at the translation initiation site of the vitamin $D$ receptor gene is associated with low bone mineral density in postmenopausal Mexican-American women. J Bone Miner Res, 1996; 11:1850-5.

He W, Liu M, Huang X, Qing Z, Gao W. The influence of vitamin $\mathrm{D}$ receptor genetic variants on bone mineral density and osteoporosis in Chinese postmenopausal women. Dis Markers, 2015; 2015: 760313.

Howard G, Andon M, Bracker M, Saltman P, Strause P. Serum trace mineral concentrations, dietary calcium intake and spinal bone mineral density in postmenopausal women. J Trace Elem Exp Med, 1992; 5:23-31.

Hyun TH, Barret-Connor J, Milne DB. Zinc intakes and plasma concentrations in men with osteoporosis the Rancho Bernardo Study. Am J Clin Nutr, 2004; 80:715-21.

Jiang LL, Zhang C, Zhang Y, Ma F, Guan Y. Associations between polymorphisms in VDR gene and the risk of osteoporosis: a metaanalysis. Arch Physiol Biochem, 2020; 6:1-8.

Kawalkar AC. A comprehensive review on osteoporosis. J Trauma, 2015; 10:3-12.

Kubota M, Yoshida S, Ikeda M, Okada Y, Arai H, Miyamoto K, Takeda E. Association between two types of vitamin D receptor gene polymorphism and bone status in premenopausal Japanese women. Calcif Tissue Int, 2001; 68:16-22.

Lerner UH. Bone remodeling in post-menopausal osteoporosis J Dent Res, 2006; 85:584-95.

Liu K, Han B, Hou J, Meng H. Preliminary investigation on the molecular mechanisms underlying the correlation between VDR-FokI genotype and periodontitis. J Periodontol, 2020; 91(3):403-12.

Liu M, Yao X, Zhu Z. Associations between serum calcium, $25(\mathrm{OH}) \mathrm{D}$ level and bone mineral density in older adults. J Orthop Surg Res, $2019 ; 14: 458$

Liu SZ, Yan H, Xu P, Li JP, Zhuang GH, Zhu BF, Lu SM. Correlation analysis between bone mineral density and serum element contents of postmenopausal women in Xi'an urban area. Biol Trace Elem Res, 2009; 131:205-14.

Moradi S, Khorrami-Nezhad L, Maghbooli Z, Hosseini B, Keshavarz SA, Mirzaei K. Vitamin D receptor gene variation, dietary intake and bone mineral density in obese women: a cross sectional study. J Nutr Sci Vitaminol (Tokyo), 2017; 63(4):228-36. 
Narula R, Tauseef M, Ahmad IA, Agarwal K, Ashok A, Anjana A. Vitamin D deficiency among postmenopausal women with osteoporosis. J Clin and Diagnostic Research, 2013; 7:336-8.

Nieves JW. Osteoporosis: the role of micronutrients. Am J Clin Nutr, 2005; 81:1232-9.

Odabasi E, Turan M, Aydin A, Akay C, Kutlu M. Magnesium, zinc, copper, manganese, and selenium levels in postmenopausal women with osteoporosis. Can magnesium play a key role in osteoporosis? Ann Acad Med Singapore, 2008; 37:564-7.

Prasad M, Rajarajeswari D, Aruna P, Ramalingam K, Viswakumar R, Fathima N, Vishwakarma SK, Khan AA. Status of vitamin $\mathrm{D}$ receptor gene polymorphism and 25-hydroxy vitamin $\mathrm{D}$ deficiency with essential hypertension. Indian J Clin Biochem, 2021; 15:1-7.

Pietschmann P, Rauner M, Sipos W, Kerschan-Schindl K. Osteoporosis: an age-related and gender-specific disease--a mini-review. Gerontology, 2009; 55(1):3-12.

Rai V, Abdo J, Agrawal S, Agrawal DK. Vitamin D receptor polymorphism and cancer: an update. Anticancer Res, 2017; 37(8):39914003.

Rana AH. Evaluation of serum osteocalcin level in Iraqi postmenopausal women with primary osteoporosis. J Fac Med Baghdad, 2013; 55:2.

Roychowdhury T, Uchino T, Tokunaga H, Ando M. Arsenic and other heavy metals in soils from an arsenic-affected area of West Bengal, India. Chemosphere. 2002; 49:605-18.

Rude RK, Gruber HE. Magnesium deficiency and osteoporosis: animal and human observations. J Nutrit Biochem, 2004; 15:710-6.

Saltman P, Strause L. Trace elements in bone metabolism. J Inorg Biochem, 1991; 3:28.

Sasmita M, Manju M, Toora BD, Mohan S, Venkatesh BP Comparison of bone mineral density and serum minerals in pre and postmenopausal women. Int J Clin trails, 2015; 2:85-90.

Si L, Winzenberg TM, Jiang Q, Chen M, Palmer AJ. Projection of osteoporosis-related fractures and costs in China: 2010-2050. Osteoporos Int, 2015; 26(7):1929-37.

Singh M, Singh P, Singh S, Juneja PK, Kaur T. Vitamin D receptor (VDR) gene polymorphism influences the risk of osteoporosis in postmenopausal women of Northwest India. Arch Osteoporos, 2013; 8:147.

Stewart TL, Ralston SH. Role of genetic factors in the pathogenesis of osteoporosis. J Endocrinol 2000; 166:235-45.

Sudjaroen Y, Thongmuang P. Bone mineral density (BMD) and bone-related biochemical markers after short-term supplementation in normal and osteoporotic elders, the pilot study. J Appl Pharm Sci, 2018; $8(12): 165-9$.

Sudjaroen Y, Thongmuang P. Calcaneal quantitative ultrasound and bone turnover markers for osteoporosis screening in elders, the providing of benefits. Asian J of Pharm, 2019; 12:S1418-23.
Sudjaroen Y, Thongmuang P. The relationship of bone mineral density (BMD), age and body mass index (BMI) among postmenopausal women, Samut Songkhram, Thailand. Int J Pharm Res, 2020; 12(4):4936-9.

Techapatiphandee M, Tammachote N, Tammachote R, Wongkularb A, Yanatatsaneejit P. VDR and TNFSF11 polymorphisms are associated with osteoporosis in Thai patients. Biomed Rep, 2018; 9(4):350-6. Valdivielso JM, Fernandez E. Vitamin D receptor polymorphisms and diseases. Clin Chim Acta, 2006; 371:1-12.

Wach S, Weigelt K, Michalke B, Lieb V, Stoehr R, Keck B, Hartmann A, Wullich B, Taubert H, Chaudhri A. Diagnostic potential of major and trace elements in the serum of bladder cancer patients. J Trace Elem Med Biol, 2018; 46:150-5.

Weaver CM, Alexander DD, Boushey CJ, Dawson-Hughes B, Lappe JM, LeBoff MS, Liu S, Looker AC, Wallace TC, Wang DD. Calcium plus vitamin D supplementation and risk of fractures: an updated metaanalysis from the National Osteoporosis Foundation. Osteoporos Int, 2016; 27(1):367-76.

Williams SA, Daigle SG, Weiss R, Wang Y, Arora T, Curtis JR. Economic burden of osteoporosis-related fractures in the US medicare population. Ann Pharmacother, 2021; 55(7):821-9.

Uitterlinden AG, Fang Y, Van Meurs JB, Pols HA, Van Leeuwen JP. Genetics and biology of vitamin D receptor polymorphisms. Gene, 2004; 338:143-56

Young DS, Bermes EW. Specimen collection and processing sources of biological variation. In: Burtis CA, Ashwood AR, (eds.). Tietz textbook of clinical chemistry. 3rd edition, Saunders, Philadelphia, PA, pp 42-72, 1999.

Zhao F, Guo L, Wang X, Zhang Y. Correlation of oxidative stress-related biomarkers with postmenopausal osteoporosis: a systematic review and meta-analysis. Arch Osteoporos, 2021; 16(1):4.

Zintzaras E, Rodopoulou P, Koukoulis GN. BsmI, TaqI, ApaI and FokI polymorphisms in the vitamin D receptor (VDR) gene and the risk of osteoporosis: a meta-analysis. Dis Markers, 2006; 22:317-26.

\section{How to cite this article:}

Sudjaroen Y, Thongkao K, Thongmuang P, Pongstaporn W, Aounchat D, Suwannahong K. VDR gene polymorphism and trace elements in Thai postmenopausal women with risk of osteoporosis: Cross-sectional study. J Appl Pharm Sci, 2022; 12(02):152-157. 